\title{
СОСТОЯНИЕ И ПЕРСПЕКТИВЫ ПРОМЫШЛЕННОГО ОСВОЕНИЯ РАКВЕРЕСКОЙ ФОСФОРИТОНОСНОЙ ПЛОЩАДИ
}

Фосфориты ракушечного типа Әстонской ССР приурочены к песчаным и алевритовым отложениям пакерортского горизонта нижнего ордовика, имеющим пластовое почти горизонтальное залегание - падение слоев на юг примерно $3 \mu$ на $1 \kappa м$.

Фосфоритоносные отложения представлены кварцевыми песками и песчаниками разной степени цементации, содержащими большое количество (от 10 до $70 \%$ ) створок беззамковых брахиопод или их обломков. Содержание полезного компонента - пятиокиси фосфора $\left(\mathrm{P}_{2} \mathrm{O}_{5}\right)$ - в чистых створках колеблется в пределах $35-37 \%$, а в фосфоритном пласте в зависимости от насыщенности породы фосфатными раковинами или их обломками варьирует от $3-4$ до $20 \%$. В подсчет промышленных запасов включаются фосфориты, содержащие $\mathrm{P}_{2} \mathrm{O}_{5}$ более $6 \%$.

Эстонские фосфориты ракушечного типа, как правило, легко обогатимы и их флотационное обогащение позволяет получить концентрат с содержанием $\mathrm{P}_{2} \mathrm{O}_{5}$ до $27-30 \%$. Такой концентрат пригоден для производства высококачественных фосфорных удобрений - двойного суперфосфата, аммофоса и др.

Наиболее крупным месторождением ракушечных фосфоритов в Эстонской ССР является разведанное в начале 70-х годов месторождение Тоолсе, расположенное в северной части Раквереского административного района. Запасы месторождения по промышленным категориям утверждены в ГКЗ СССР и переданы Министерству химической промышленности для освоения.

Поисковыми работами, выполненными в последние годы Управлением геологии Әстонской ССР южнее месторождения Тоолсе, на большей части Раквереского района установлено наличие перспективных для промышленности фосфоритов. Общая опоискованная площадь составляет здесь более $1500 \kappa \mu^{2}$. На открытой Раквереской фосфоритоносной площади промышленный пласт фосфоритов имеет непрерывное распространение. Мощность пласта колеблется от 1,5 до $10-12$, в среднем 4,0 $\boldsymbol{M}$. Среднее содержание $\mathrm{P}_{2} \mathrm{O}_{5}$ в фосфоритном пласте $10-10,5 \%$, а в отдельных скважинах достигает $15-20 \%$. Прогнозные запасы фосфоритов новой Раквереской фосфоритоносной площади превышают запасы месторождения Тоолсе более чем в 10 раз. Фосфорито-

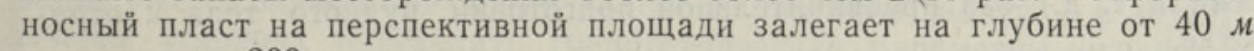
на севере до $200 \mu$ на юге.

Непосредственно в кровле фосфоритного пласта залегают глинистые битуминозные (диктионемовые) сланцы и сланцеватые глины мощ- 
ностью $1-3 м$ и глауконитовые песчаники мощностью $0,5-1,0$. Битуминозные сланцы и сланцеватые глины распространены только в северной части района, а глауконитовые песчаники, уменьшаясь в мощности по направлению к югу, имеют повсеместное распространение. Выше залегает мощная толща слоистых известняков нижнего и среднего ордовика.

В ходе поисковых работ установлено, что литологический и качественный состав фосфоритного пласта Раквереской площади отличается от литологического состава фосфоритного пласта месторождения Тоолсе. В результате фациальных замещений, связанных с изменением палеогеографической обстановки накопления осадков, образование богатых, крепко сцементированных ракушечников произошло в верхней части фосфоритного пласта. Вниз по разрезу наблюдается постепенное обеднение фосфоритного пласта $\mathrm{P}_{2} \mathrm{O}_{5}$ и уменьшение количества прослоев сцементированных разностей.

Что касается освоенности территории этого района, то следует подчеркнуть, что он относится к районам интенсивного развития сельскохозяйственного производства, в основном животноводческого направления. Сельскохозяйственные земли высокоплодородны. Среднегодовые урожаи зерновых культур достигают 30-40 центнеров с гектара. Кроме того, значительная часть площади занята лесными массивами I категории. Отсюда становится очевидным, что возможная горнодобывающая промышленность здесь должна быть организована с учетом минимального ущерба для сельского и лесного хозяйств республики.

Изложенные особенности геологического строения и характеристика поверхности Раквереской фосфоритоносной площади позволяют уже на данной стадии изученности сделать некоторые выводы о горнотехнических условиях будущей отработки выявленных запасов.

Из сказанного вытекает, что отработка фосфоритов Раквереского района целесообразна только подземным (шахтным) способом. Положительными факторами при подземной отработке являются: достаточная мощность фосфоритного пласта, локальная цементация верхней части пласта и сокращение мощности или выклинивание малоустойчивых пород кровли (диктионемовые сланцы, сланцеватые глины и глауконитовые песчаники). Осложняющими факторами при шахтном вскрытии и подземной отработке могут быть значительные водопритоки и большие мощности фосфоритного пласта.

По данным гидрогеологических исследований дебит водоносных горизонтов в южной части месторождения Тоолсе составляет по отдель-

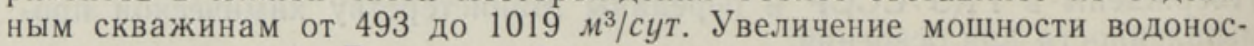
ных горизонтов на Раквереской площади влечет за собой и увеличение водообильности пород, которая может достигнуть 2000-2500 м $^{3} / c y т$. Предполагаемые здесь водопритоки в подземные выработки требуют разработки специальных мероприятий по осушению и водоотливу, например, организацию опережающего дренажа.

Как указывалось выше, мощность фосфоритного пласта со слабой устойчивостью слагающих его пород на рассматриваемой площади достигает в отдельных случаях 12,0 , составляя в среднем 4,0 м. Горногеологические условия с учетом изложенных выше данных, по-видимому, не позволяют применять при проектировании шахт известные классические системы разработки (камерно-столбовую, отработку лавами и т. д.) без предварительной подготовки рудного тела к отработке.

Принимая во внимание геологическую специфику продуктивной толщи, целесообразно испытать на ракушечных фосфоритах один из ва- 
риантов особой системы отработки, разработанной ГИГХС на основе детального анализа опыта разработки пластовых месторождений и технических средств, обеспечивающих селективную выемку полезного ископаемого.

1. Отработка длинными очистными забоями (механизированными лавами с гидрофицированными крепями).

1.1. Вариант традиционный - отработка комплексом типа ОКП с обрушением кровли. Учитывая небольшой доступ воздуха в выработанное пространство и заиливание разрушенных битуминозных (диктионемовых) сланцев, расположенных выше сланцевых глин, можно предположить, что их самовозгорание будет этим исключено. Забутовка вынутой части пласта породами непосредственной кровли обеспечит приемлемое опускание поверхности.

1.2. Вариант камера-лава. Панель длиной 250-300 м нарезается подготовительными выработками через 20 м комбайнами типа 4 ПП-2. Выработки заполняются закладкой, после чего пространство между целиками отрабатывается с применением гидрофицированных крепей ОКП. Отработка производится без обрушения кровли.

В обоих случаях отбойка производится комбайнами типа КШ-1КГ с увеличенным верхним барабаном, что позволяет селективно отрабатывать фосфоритный пласт. Использование варианта 1.2 позволяет значительно уменьшить количество гидравлических секций, учитывая необходимость только поддержания кровли.

2. Отработка короткими очистными забоями (камера с отбойкой комбайнами 4ПП-2). Панель длиной 100 м нарезается подготовительными выработками через 8 комбайнами 4 КП-2. Выработки, как и в варианте 1.2 , заполняются закладкой, после чего пространство между целиками отрабатывается камерами в два захода (две ширины комбайна). В этом варианте, как и в варианте 1.2 , требуется некоторая модернизация исполнительного органа угольного комбайна для условий ракушечных фосфоритов. Данные предложения по системе работ и механизации обеспечат:

устойчивость потолочины и вышележащих пород;

селективную выемку фосфоритного пласта;

безопасность от самовозгорания сланцев;

сокращение трудоемкости и объема работ по закладке отработанного пространства.

Ранжировка предлагаемых вариантов с точки зрения безопасности ведения работ следующая: камерная, камера-лава, лава с обрушением. Технология выемки фосфоритного пласта мощностью более $4,0 \mathrm{~m}$ требует уточнения после проведения детальной разведки месторождения.

Приведенные соображения о возможности без больших потерь и с опережающим водоотливом отрабатывать шахтные поля с запасами ракушечных фосфоритов требуют, однако, экспериментальной проверки в конкретных условиях месторождения, в процессе которой можно было бы получить исходные данные для проектирования нанболее целесообразного варианта системы вскрытия и отработки.

С этой целью необходимо на характерном участке разведанной площади уже в ближайшее время заложить опытную шахту и в естественных условиях определить горнотехнические параметры отработки месторождения: устойчивость кровли, величину водопритоков, размеры очистных камер, прочность материала и технологию закладки нарезных 
штреков и т. д. От принципиального решения ряда технических вопросов будущей эксплуатации зависят эффективность и последовательность проведения разведочных работ на Раквереской перспективной площади.

В заключение следует сказать, что быстрейшее детальное изучение Раквереской фосфоритоносной площади с последующим строительством в республике крупного горнохимического предприятия по производству высококачественного фосфоритового концентрата будет иметь исключительно важное значение для развития народного хозяйства северо-запада нашей страны. Освоение нового фосфоритоносного района в значительной степени улучшит обеспечение страны высококачественными фосфорными удобрениями.

Управление геологии Эстонской ССР

Поступила в редакцию 1/XII 1980

E. PETROSJANTS, V. ZAGURAJEV, A. KIVIT, E. MUSTJOGI

\title{
RAKVERE FOSFORIIDIVÄLJA TÖOOSTUSLIKU KASUTAMISE PERSPEKTIIVID
}

Viimastel aastatel avastatud uue Rakvere fosforiidivälja (pindala üle $1500 \mathrm{~km}^{2}$ ) prognoossed varud ületavad rohkem kui 10 korda senised uuritud varud. Fosforiidikiht (keskmine paksus $4 \mathrm{~m}$ ja $\mathrm{P}_{2} \mathrm{O}_{5}$ sisaldus $10 \%$ ) lasub siin $40-200 \mathrm{~m}$ sügavuses ja on kättesaadav ainult maa-alusel kaevandamisel. Artiklis on pakudud kaks kaevandamisvarianti - kaevandamine mehhaniseeritud pikkades laavades või kamberlaavades ja kambriviisiline kaevandamine kombainidega. Kaevandamismetoodika täpsustamiseks on vajalik katsekaevanduse rajamine.

\author{
E. PETROSYANTS, V. ZAGURAYEV, A. KIVIT, E. MUSTJOGI
}

\section{THE STATE AND PROSPECTS OF INDUSTRIAL EXPLOITATION OF THE RAKVERE PHOSPHORITE FIELD}

The Rakvere phosphorite field, discovered a few years ago, covers an area of ca $1500 \mathrm{~km}^{2}$. The phosphorite reserves of the field exceed the previously known ones about 10 times. The workable seam lies at a depth of $40-200 \mathrm{~m}$, its average thickness is $4 \mathrm{~m}$ and the content of $\mathrm{P}_{2} \mathrm{O}_{5}$ is $10 \%$. The authors propose two variants of mining methods which ought to be tested in an experimental mine. 